\title{
An Analysis Of Brand Equity Determinants: Gross Profit, Advertising, Research, And Development
}

David J. Smith, (E-mail: david_smith@pba.edu), Palm Beach Atlantic University

Nikola Gradojevic

W. Sean Irwin

\begin{abstract}
The topic of brand equity continues to be of great importance to private sector firms in the creation and development of both product and company brand strategy. This study analyzes the relationship of different variables and brand equity with the purpose of providing useful insight into brand management and advancement. This research approach is unique in its use of private sector generated measures of brand equity as the main data source. The methodology entails collecting financial information from a list of publicly traded companies evident on the annual Interbrand ranking of top brand values, then executing statistical analysis using correlation and regression. Results make evident a significant positive correlation between brand equity and gross profit, advertising expense, and research and development expense. However, findings reveal that advertising is not as important a driver of brand equity in the short-term as put forward in previous research and evidence suggesting the presence of dynamics and non-linear effects exists.
\end{abstract}

\section{INTRODUCTION}

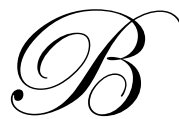

rand equity has received a great deal of research interest in the past 15 years and continues to be one of the most appealing fields of marketing for private sector firms. Brand equity issues are important in the design and development of a company and its product or service offerings. However, academics have not achieved a robust or widely accepted methodology of measuring a firm's brand equity or the effect of different variables on the valuation of a brand. The purpose here is not to develop an acceptable methodology for valuating brand equity, but rather to make observations based on the correlation of brand equity with selected variables in order to better understand the constructs.

The importance of evaluating brand equity is clearly visible in recent merger and acquisition activity. The 2005 acquisition of Gillette Company by Proctor and Gamble illustrated this as the purchase price of $\$ 57$ billion was 19 times Gillette's earnings before interest, taxes, and depreciation (Byrnes 2005). Why was the acquisition price so large? The value and perceived future earnings of the brands acquired in the deal - Gillette, Duracell, Braun and Oral-B played a large part in the determination of the purchase price.

Researchers have also found that brands with high brand equity receive a considerable purchase price, even when a company has declared bankruptcy (Kaikati and Kaikati 2003). Converse, Bugle Boy, and Schwinn are noted examples of this, selling for $\$ 117.5$ million, $\$ 68.6$ million, and more than $\$ 60$ million respectively, suggesting that high brand equity can provide rewards even when a company is in a poor financial position. Brand equity is recognized in the name and symbols associated with a company, and the very act of social responsibility is believed to be a significant driver for building brand equity (Wood 2004). The direction a company takes in assisting the general public, or dealing with a corporate mistake, assist consumers in building attitudes and associations towards a specific brand and results in reinforcing their purchase behaviors. 
What does all of this research mean? Brand equity is felt in all areas of the production and promotion of a product, and improved insight of the factors that build brand equity will provide financial rewards to companies. This has been an important research topic for the production of goods for centuries, and is now receiving attention in the field of services. Berry (2000) concluded that branding will be the cornerstone of services marketing for the twenty-first century.

Mahajan et al. (1994) described the results of brand equity as:

- $\quad$ Enhanced performance (for example, increase in market share or increase in revenues due to the firm's ability to charge a premium price) and/or marketing efficiency (for example, reduced advertising and promotional expenditures) associated with the brand.

- Longevity (or vulnerability) of a brand due to its loyal customer base and distribution relationships, and

- $\quad$ Carryover potential (or extensibility) to other brands and markets of the acquiring firm

The main points - enhanced performance and/or marketing efficiency, longevity or vulnerability, and carryover potential, are the key reasons why companies invest so heavily in the development and management of a company or product brand name.

Although it has not been thoroughly examined in each specific market, high brand equity usually results in enhanced performance and marketing efficiency (Aaker 1991). One only has to examine the amount of advertising dollars being used toward building brand awareness and the financial performance of companies with perceived high brand equity to determine the value of building and maintaining high brand recognition in the minds of consumers. This is substantiated by the research of Bristow et al (2002), who found the top 200 brands, in terms of dollars, were committed to advertising, spending over $\$ 7$ billion to promote their brand names with consumers.

The longevity advantage of an established brand name in a market is easily identifiable. Aaker (1991) utilized the research results of the Boston Consulting Group to reinforce the longevity presumption. The results noticeably demonstrate that a recognized brand name usually results in successful longevity, as most of the market leaders identified from 1925 maintained their industry leading position in 1985. The BCG research included some of today's most significant brand names including Coca-Cola, Gillette, Singer, Campbell's and Kellogg's.

Additional research has revealed that companies will pay a premium to acquire or merge with a competitor that has recognized high brand equity as a means of hedging against new product costs (Mahajan et al. 1994). Purchasing a company or product line with high brand awareness has a high potential for carryover to the new parent company, as long as the brand name remains intact and consumers do not see a visible reduction in performance. This is a principal driver of acquisitions like the before mentioned deal involving Proctor and Gamble purchasing Gillette and its sub brands. Proctor and Gamble traditionally market their goods under the individual product level brand name and not the parent company, so acquiring a recognized name like Gillette will reduce possible risks and remove a potential competitor. The carryover potential of a brand name is also experienced in the prospects of brand extensions. Brand extensions are visible in a variety of industries and are regularly successful, especially when compared to the large costs of bringing a new product to market.

\section{CONCEPTUAL BACKGROUND}

The practice of branding has been conducted for centuries as a means for producers to distinguish their goods against those of competitors by creating a recognizable and memorable image. Farquhar (1989) states "A brand is a name, symbol, design, or mark that enhances the value of a product beyond its functional purpose". The term brand equity first came into wide spread use in the 1980s and was defined as "The 'added value' with which a brand endows a product." (Farquhar 1989). This may be deemed a rather straightforward and raw definition, but it has served as the springboard of future research. 
Aaker (1991) presents one of the most detailed and widely accepted definitions of brand equity as "A set of brand assets and liabilities linked to a brand, its name and symbol that add or subtract from the value provided to a firm and/or to that firm's customers." He developed the following model to illustrate his definition (See Figure 1):

The model demonstrates that brand equity is developed based on the five dimensions of brand loyalty, name awareness, perceived quality, brand associations, and other proprietary brands assets (ex. distribution system). How the brand performs on these dimensions is what leads consumers to develop an overall, intangible rating of brand equity. This equity then provides value to the consumer and the firm in the outlined ways. The model by Aaker was one of the first seminal works in the field of brand equity and led to future research in the area.

Figure 1: Aaker's Brand Equity Model

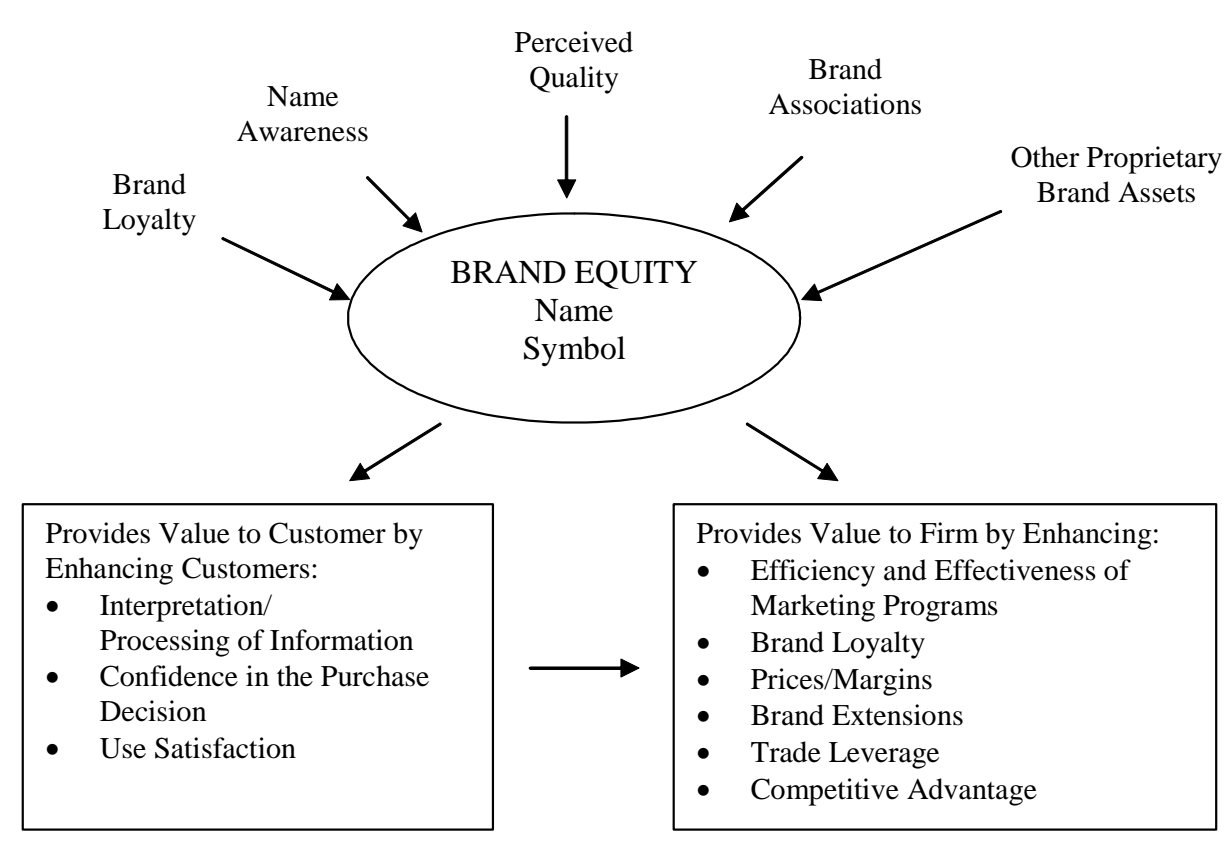

It seemed that with the definitions of brand equity offered by Farquhar and Aaker, and subsequent references to the validity of these definitions (Keller 1993; Simon and Suillivan 1993; Mahajan et al. 1994) that the area of brand equity may be moving forward and gaining acceptance. However, in 1996, critics of the legitimacy of brand equity surfaced and an academic debate began.

One of the first critical articles of brand equity (Feldwick 1996) finds that the term brand equity has three different meanings depending on your use. At any one time brand equity can be used to refer to brand description (consumer associations with the brand name), brand strength (similar to Aaker as a measure of relative consumer demand for the brand), and brand value (to set a price of the brand for when it is sold). Feldwick argues that brand equity is a vague concept especially due to its lack of measurability and application in the business environment. He concludes that brand equity is too imprecise to be used as the holistic measure of everything that a company should be doing to improve its future performance.

As Feldwick was contending against brand equity, Kotler et al. (1996) was supporting the conclusions of Farquhar and Aaker by defining brand equity as "The value of a brand, based on the extent to which it has high brand loyalty, name awareness, perceived quality, strong brand associations, and other assets such as patents, trademarks, and channel relationships." Kotler did not directly counter the assertions of Feldwick, but gave a highly 
credible voice to the validity of the topic subject. This was further reinforced by Agarwal et al (1996) who conducted research into the validity of different measures of brand equity.

Aaker's subsequent work (1996) (See Figure 2) added to his earlier findings, making the model more encompassing of different markets with modifications based on updated research. The following diagram illustrates the ten measures of brand equity. This debate continued as Ehrenberg (1997a) built upon earlier arguments against brand equity by reasserting the lack of tangibility and clear definition of the concept. He argued that high brand equity is due to large sales and a sizeable advertising budget, since consumers are more likely to favor the larger brand names. However, Baldinger and Rubinson (1997) argued against the assertions of Ehrenberg by showing research that customer attitudes can be measured with some level of validity and that brands (large or small) do show a decrease in strength when observed over a long period of time.

Figure 2: Ten Brand Equity Dimensions

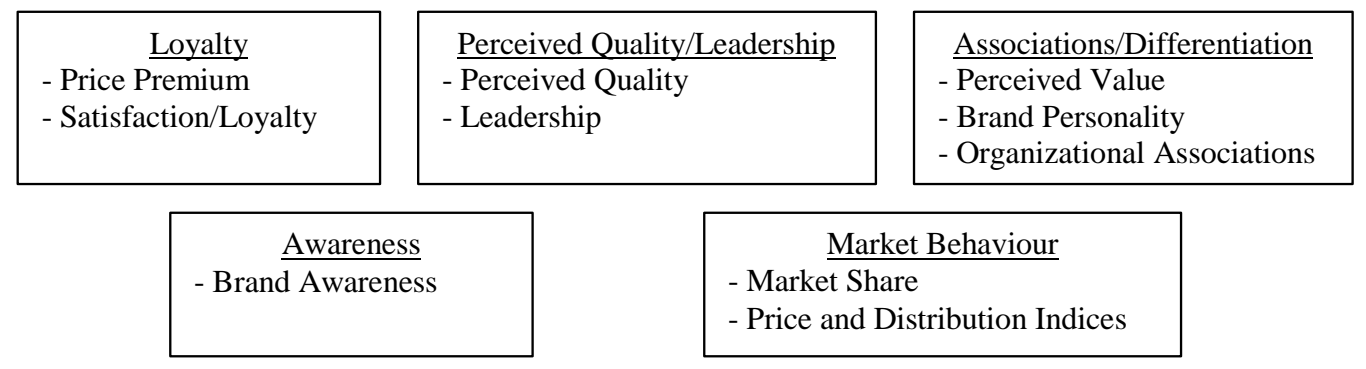

Ehrenberg (1997b) also debated against brand equity because competitive brands are unable to gain significant differentiation since a unique brand will be quickly copied and any successful advertising will also be imitated by the competition. This lack of long-term originality or sustainable differentiation translates into a brand's equity being quickly mitigated or reduced by the competition. Cook (1997) further added weight to Ehrenberg's case in explaining that although advertising must be perceived as original and unique in order to gain new clients, it rarely results in a substantial positive or negative gain for brand equity due to long-term product and company lifecycles. Farr and Hollis (1997) contend that a series of short term gains received as a result of advertising campaigns (albeit replicated by the competition or not) are one of the drivers of the long-term success of a brand and consequentially in developing substantial brand equity.

Other authors have also tried to provide some insight and credence to the field of branding and brand equity by reducing the ambiguity in the term and misinterpretation regarding the use of similar terms. Faircloth, Capella and Alford (2001) developed a stage model that shows the attitude consumer's form regarding a brand leads to the image the brand takes in their mind. Brand attitude does not fully explain brand equity, but rather contributes to the framing of a brand image, which will lead to positive or negative brand equity. Moving from one stage to the next does not involve a full transfer of beliefs and feelings, but rather they lead to the full development of a brand in a consumers mind.

Chen (2001) (See Figure 3) identifies the types of brand associations and examines the relationship between the characteristics of brand associations and brand equity. He uses the research of Aaker (1991) to develop his model concluding that the underlying value of a brand name is often a set of 11 associations. Chen suggests classifying brand association into product and organizational associations and further sub-associations as outlined in his brand association model.

Chen provides useable examples for the functional attribute associations and non-functional attribute associations to increase the readers understanding of the framework. He then conducts his research to determine the effect of brand associations on brand equity. 
Apelbaum, Gerstner, and Naik (2003) highlight the difference in price provided by brand awareness and examine whether quality is as much a price determinant as brand equity. The authors study the variations in product quality between national and store brands from selected Consumer Reports lists and compare the use of premium pricing. The authors find that quality differences between national and store brands vary significantly across product categories and for 25 percent of product categories, the average quality of store brands is higher. In spite of this difference in quality, national brands receive a substantial price premium (30 percent on average) and when the quality of national brands is higher than store brands the price premium increases to 50 percent.

Figure 3: Chen Brand Association Model

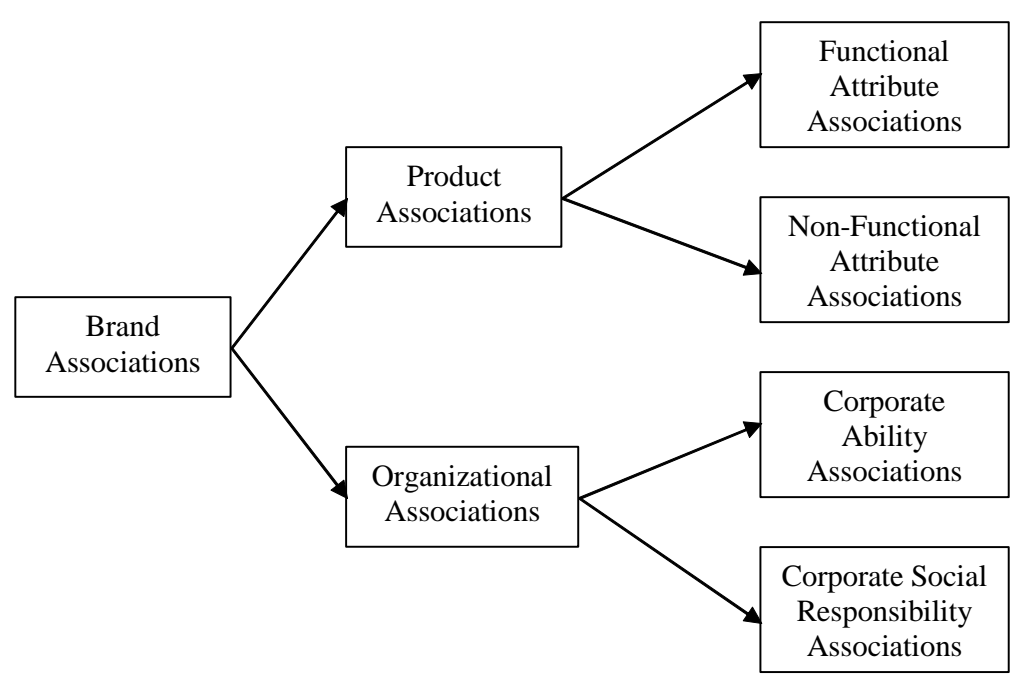

\section{CUSTOMER-BASED BRAND EQUITY MEASUREMENT}

Aaker (1991) was the first to propose a means of assessing customer-based brand equity measurements. He supports that brand equity is measured by how consumers perceive a brand in regards to brand loyalty, name awareness, perceived quality, brand associations, and other proprietary brands assets. This measurement is to be established by surveying customers directly to determine satisfaction and perceptions regarding a brand and its equity.

Keller (1993) carried the research of Aaker one step further by defining and outlining customer-based brand equity measurement methods and encouraging managers to think more strategically about brand equity. Keller defines customer-based brand equity as the differential effect of brand knowledge on consumer response to the marketing of a brand. He views the measurement in a broad manner as a brand has positive (or negative) customerbased brand equity if consumers react more (or less) favorably to the product, price, promotion, or distribution of the brand than they do to the same marketing mix when it is attributed to an unbranded version of the product or service. Keller suggests an indirect approach using multiple measures, including aided and unaided memory measures, to determine the level of brand awareness by consumers. He then offers a direct approach, using experiments on branded and unbranded products (ex. blind taste test), to determine the effects of brand knowledge on consumer response, believing that there is no one specific measure of brand equity and different measures used in cooperation lead to the best measurement tool.

In keeping with the definition of customer-based brand equity measures, Park and Srinivasan (1994) developed a survey-based method of measurement. Their method is intended to gather different customer opinions and attitudes to determine possible factors in building brand equity, which will assist brand managers in making 
informed decisions. By collecting data on the importance of attribute and non-attribute based factors, brand managers can determine how the company's brand rates compared to the competition and plan for the future direction of the brand. Another customer-based measure develops a scale to examine the brand equity dimensions of performance, value, social image, trustworthiness, and commitment (Lassar et al 1995). Using a 17 point scale, which correlated significantly with an overall measure of brand equity, the survey tool is able to accurately assess with some level of confidence, customer opinions and brand equity drivers. Finally, Agarwal and Rao (1996) (See Figure 4) tested the convergence and predictive validity of 11 measures of customer based brand equity. The following eleven measures, except M1 - Recall, demonstrated convergence:

Figure 4: Eleven Measures of Customer-Based Brand Equity

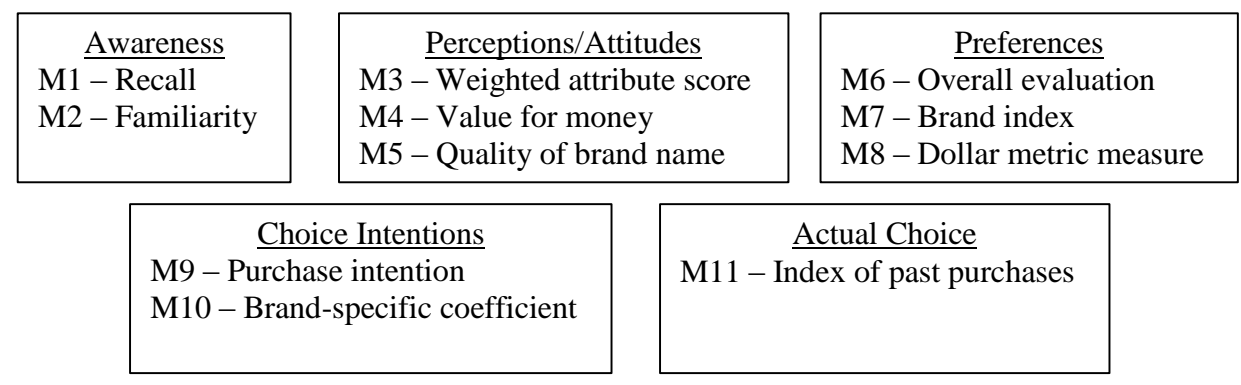

Yoo and Donthu (2001) propose a multidimensional consumer-based brand equity scale based on the research of Aaker and Keller. The authors develop a scale utilizing 22 items for assessment: five on brand loyalty, four on brand awareness, seven on perceived quality, and six on brand associations. Washburn and Plank (2002) conducted an independent assessment of the Yoo and Donthu scale and in some ways supported their findings, but had serious reservations after the exposure of residual problems. Washburn and Plank view Yoo and Donthu's scale as a valued initial step in developing a recognized tool for measuring consumer-based brand equity.

\section{FINANCIAL-BASED BRAND EQUITY MEASUREMENT}

Whereas the consumer-based method of measuring brand equity is based on the feedback of consumers, the financial-based brand equity methods are more focused on valuating brand equity upon financial performance. This methodology involves highlighting key financial measures and factoring these results into a formula for evaluating brands. Winters (1991) provides three methods accountants use when determining the value of a brand as:

1. Market approach - present value of the future economic benefits to be derived by the owner of a property.

2. Cost approach - amount of money required to replace a brand, including the costs of product development, test marketing, advertising, etc.

3. Income approach - net income derived from the brand divided by the risks associated with the brand achieving the prospective earnings.

However, accountants usually price a brand at four to six times the annual profit realized from the sale of the branded product. Winters believes there is general disagreement over the different means of valuating brand equity and that this disparity has resulted in numerous different valuation methods being utilized.

In comparison to Keller (1993) and his insights on customer-based brand equity, Simon and Sullivan (1993) make available the means to examine brand equity through a financial approach. The authors present a financial technique based on financial market estimates of brand-related profits. The method for the financial approach takes into consideration expenditures on advertising and research and development, company market share, age of the firm, and market concentration in combination with tested dummy variables. The article also shows support that marketing events (ex. a new product launch) have a significant effect on brand equity. The results 
provide evidence that brand equity comprises a large percentage of the total value of many firms and gives weight to the belief that brands must be managed effectively.

One of the first articles to utilize a private sector measure of brand equity was put forth by Baderhausen (1995). The Financial World (later renamed Business Week) uses a measurement methodology condensed from the formula used by Interbrand Corporation. The method involved collating industry ratio's (ex. gross profit margin) and then attributing a brand strength multiple to the different brand sample. These ratios were then examined against the industry norm's to determine if the company's brand was being over or under-utilized

Motameni and Shahrokhi (1998) present an overview of some of the viewpoints and work towards a global financial perspective on brand equity valuation. The study proposes a global perspective, similar to the Interbrand Group formula, based on a brand's net earnings (differential earnings of a branded and an unbranded product) multiplied by different multiples involving importance and customer, competitor, and global potency. The model utilizes some of the research conducted by Simon and Sullivan (1993) in its development, but does not test its findings on actual businesses within this study.

Seetharaman, Nadzir, and Gunalan (2001) conduct an examination of current brand valuation techniques and how they can be applied to the balance sheet. The main goal of their study is to select one of four existing approaches as the best method to value a brand. The four approaches of valuation are: Cost-based approach: "a brand is valued by considering the cost involved in developing the brand." Market-based approach: ".. based on the amount at which a brand can be sold. To determine its market value, the future benefits associated with owning the brand are included and are discounted to the present value." Income-based approach: "focuses on the future potential of a brand ... determination of the future net revenues attributable to the brand and discounting to the present value." Formulary approach: "involves multiple criteria in determining a brand's value ... including leadership, stability, market, support, protection, international image, and trend."

\section{VARIABLES ASSOCIATED WITH BRAND EQUITY}

Gross profit is a perceptible indicator of high brand equity as it demonstrates the amount a consumer is willing to pay above the actual costs of production of a good or service. The gross profit margin can be compared against the competition to determine any noticeable difference in return percentages, suggesting a likely premium brand performance.

Farquhar, (1989) early on, suggests the result of high brand equity may be the allowance of premium pricing for a product. A successful brand with high equity is able to charge more for its products and thus receive a higher return or gross profit when compared to other companies. This was reinforced by Aaker (1991) who believes that a brand possessing high ratings in the dimensions of name awareness, perceived quality, associations, and loyalty is able to charge more for its products. Aaker (1996) further points out that the most suitable method for determining brand equity may be using conjoint analysis to establish how much more a consumer is willing to spend on one brand product versus another.

Appelbaum (2003) examined the amount of price premium commanded by a national brand versus a store brand and found that although the quality may be higher for the store brand (22 out of 78 instances based on data from consumer reports), national brands (which can be assumed to possess higher brand equity) typically charge a price premium. This offers that although a branded product may only have perceived product quality when compared to competitive offerings, other dimensions of brand equity (ex. name awareness) may allow for a company to charge a higher price and/or receive a higher gross profit. Similar research has supported the findings of Appelbaum in that revenue premium is related to brand equity. Ailwadi et al. (2003) established that revenue premium is a reliable measure of brand equity and presents an adequate picture of a brands health in the long-term 
Advertising is another obvious variable that one would assume to have a relationship with brand equity. It is seen as one of the most important means of establishing brand awareness and educating consumers on the different attributes or dimensions of a brand. Aaker (1991) frequently indicated that advertising was important to the building of consumer perceptions in the five dimensions of brand loyalty, name awareness, perceived quality, brand associations, and other proprietary brands assets. Aaker further proposed that advertising may be the key driver of brand equity through the means of cumulative advertising and possessing a higher share of industry advertising.

Simon and Sullivan (1993) use advertising as a variable related to market share in the development of a financial-based measure of brand equity. Cobb-Walgren, Ruble, and Donthu (1995) conclude that companies with higher advertising budgets possessed higher levels of brand equity when compared to companies with smaller advertising budgets. Furthermore, Yoo and Donthu (2000) found that frequent price promotions are related to low brand equity while high advertising spending, high price, good store image, and high distribution intensity are related to high brand equity.

Examining the relationship between brand equity and advertising presents two main problems. Firstly, there is no infallible method of determining effective and non-effective advertising expenditures. It can be reasonably assumed that not all advertising has the desired effect and that some advertising campaigns may actually have a negative effect. Secondly, advertising is often evaluated from a short-term perspective. This may not be the most suitable research period since it has been found that the impact of advertising usually takes years to have the desired effect on brand equity (Aaker 1991).

Research and development costs are also seen as important in the long-term view of building brand equity. Companies that are reactionary to changes in the marketplace rarely possess high brand equity and are frequently followers of those that do. A company must have a long-term view in building brand equity because branding will usually involve a great deal of short-term costs, but provide the potential for a promising long-term future. Consider the example of Intel Corporation, the market-leader in the production of computer processors. The company invests heavily in research and development so it will stay one step ahead of the competition and as a result be able to execute a skimming pricing strategy. The company is known as the product innovator and commonly first to market with its products that are perceived as the most advanced. As a result of its high expenditures in research and development, the company is able to command a high initial price while the competition seeks to duplicate its technology and then Intel reduces the cost when its current product offering is no longer the only advanced option for consumers.

\section{METHODOLOGY}

Previous research on brand equity has provided reasonable support for the legitimacy of the topic; however there has been an absence of research on the direct relationship with different independent variables. Researchers have theorized and rationalized the validity of including different variables in designing measurements for brand equity, although limited research has been conducted to reverse engineer acceptable methods to determine relationships of variables based on historical data.

The objective of this study is to examine the correlation between brand equity with gross profit, advertising expense, and research and development expense. The dependent variable of brand equity is based on individual company amounts reported by Interbrand Corporation in its annual ranking of the best global brands. The annual reporting of Interbrand is recognized as a reputable valuation source of brand equity. Interbrand Corporation was created in 1974 and developed its brand valuation technique in the late 1980's. The technique is based on identifying the net present value of the expected earnings attributable to the brand. Interbrand segments companies into mutually exclusive groups and conducts a financial analysis (based on company annual reports) to determine the expected future earnings. Interbrand utilizes industry feedback and market research to examine the role of the brand in the company's sales, develop an assessment of the brand's strength and future risk, and conclude with an overall brand value. Interbrand uses their technique to satisfy the valuation needs of its customers, as well as in the production of its annual list of the best global brands in partnership with the publications Financial World and Business Week and the effectiveness of the Interbrand valuation method has been noted by numerous researchers 
including Farquhar 1989; Keller 1993; Tollington 1999; and Seetharaman et al. 2001. For the independent variables, secondary data has been collected and collated using publicly available annual reports and $10-\mathrm{K}$ forms.

Specifically the four propositions are:

$\mathrm{P}_{1}: \quad$ Gross Profit is positively correlated to Brand Equity

$\mathrm{P}_{2}$ : $\quad$ Advertising Expense is positively correlated to Brand Equity

$\mathrm{P}_{3}$ : $\quad$ Research and Development Expense is positively correlated to Brand Equity

$\mathrm{P}_{4}$ : $\quad$ Gross Profit, Advertising Expense, and Research and Development Expense significantly explain Brand Equity

An examination of causality could not be accomplished as the Granger test for causality (Granger, 1969) is defined for time-series data and this study has an insufficient number of observations along that dimension. Consequently, a pooled cross-sectional data set was constructed.

\section{SAMPLE DATA}

Six years of data (1999 - 2004) have been collected from the Business Week published annual report of the best global brands. Although the annual report lists the top 100 brands inferring that there should be 600 observations, the actual sample size is much smaller at 198 observations. This is because for ease of collection and reliability of research, some specific observations have been removed.

Firstly, since Interbrand and Business Week publish results in US dollars, only companies that issue annual reports with US dollars will be included in the data source. Secondly, some of the brand names reported by Interbrand are for specific brands within large multi-brand corporations and separating financial results is difficult. An example of this would be the Pepsi brand, which is the second largest brand to Frito-Lay within the company Pepsi-Co. Thirdly, some companies do not fully report the financial results needed for this study.

It must also be noted that some specific companies have been removed from study by Interbrand in the development of its annual report. Interbrand only includes companies that fulfill three criteria: 1) brand values greater than \$1 Billion, 2) global in nature - one third of sales from outside of the home country, and 3) produce publicly available marketing and financial data. This has excluded large brand names like Wal-Mart, American Airlines, and Mars. Some challenges were encountered while collecting data, usually in the form of company's restating financial reports years later due to changes in accounting practices or after investigation by the Securities and Exchange Commission (SEC). For the purpose of this study, original data has been used rather than data later restated by the company.

Overall, 198 observations have been collected from a variety of international companies. The companies included for research are classified in the following industries with number of individual company observations in brackets: Computer Technology (8), Web Services (3), Electronics (4), Professional Services (7), Food Services and Production (7), Clothing Production and Retail (4), Automobile Production (3) and Other (7). In total there are 43 individual companies represented in the sample.

\section{DATA ANALYSIS}

\section{Correlation}

Using Pearson's Correlation, results show that brand equity and gross profit are correlated at a 0.01 level of significance. This demonstrates that the relationship between the two variables is positive, implying that a higher gross profit generates a higher level of brand equity. The resulting correlation was expected and confirms $\mathrm{P}_{1}$, gross profit is positively correlated to brand equity. The correlation analysis including a one year lag also offers a mildly stronger positive correlation between brand equity and gross profit. 
When examining the correlation of brand equity and advertising, results show a positive significant relationship at the 0.01 level, implying that higher expenditures in advertising result in higher levels of brand equity, similar to gross profit. This finding supports $\mathrm{P}_{2}$, advertising expense is positively correlated to brand equity. Using a one year lag also indicates a stronger positive correlation between brand equity and advertising expenses at .511 versus .485 without the lag.

Lastly, the correlation between brand equity and research and development expense is observed. As expected, the relationship is positively correlated at the 0.01 significance level suggesting that higher expenditures in research and development results in higher levels of brand equity. Therefore, the results do support $\mathrm{P}_{3}$, research and development expense is positively correlated to brand equity. When a one year lag is included, no change in the correlation strength occurs.

The findings of this study support most previous literature. The correlation of gross profit confirms the relationship between brand equity and a price premium as argued by early pundits. The results also indicate a moderately strong positive relationship between advertising expense and brand equity. Although one would deduce that advertising expense may have the highest correlation of the variables included, it in fact has a weaker correlation than both gross profit and research and development. This weaker than expected relationship challenges the supposition in previous work that advertising expense may be the key driver of building brand equity (Aaker 1991). However, the findings do support the research of Cobb-Walgren et al. (1995) that companies with higher advertising budgets possessed higher levels of brands equity when compared to companies with smaller advertising budgets, as well as the findings of Yoo and Donthu (2000) that high advertising spending, high price, good store image, and high distribution intensity are related to high brand equity. Findings also put forward a fairly strong positive correlation between research and development expense and brand equity suggesting that expenditures in research and development will result in a positive effect on brand equity.

Table 1: Correlation with Interbrand Brand Equity Measures

\begin{tabular}{|c|c|c|c|}
\hline Independent Variables & $\mathbf{n}$ & $\begin{array}{c}\text { Pearson } \\
\text { Correlation }\end{array}$ & Significance \\
\hline Gross Profit & 168 & .542 & .000 \\
\hline Gross Profit with Lag & 167 & .578 & .000 \\
\hline Advertising Expense & 198 & .485 & .000 \\
\hline $\begin{array}{c}\text { Advertising Expense with } \\
\text { Lag }\end{array}$ & 194 & .511 & .000 \\
\hline R \& D Expense & 108 & .538 & .000 \\
\hline R \& D Expense with Lag & 105 & .538 & .000 \\
\hline
\end{tabular}

Correlation is significant at 0.01 for all variables (two-tailed)

\section{Regression}

Table 2 reports the results of the least squares estimation for several model specifications. The dependent variable is brand equity and the explanatory variables for regressions (1) - (6) are selected (or derived) from gross profit $(g p)$, advertising expense $(a e)$, and research and development expense $(r d e)$.

The first regression (1) that is supposed to account for all the considered explanatory variables indicates that advertising expense is the only estimate not statistically different from zero. Moreover, the sign of this estimate is negative and, thus contradicts the previous evidence on the explanatory power of advertising expense. However, regression (2) shows that when advertising expense is omitted, the $\bar{R}^{2}$ decreases from 0.5739 to 0.2916 . In addition, the Ramsey RESET test supports the notion that the advertising expense variable is informative for brand equity. Whether our findings represent a small sample bias remains to be investigated. 
Regression (3) looks for dynamics in the model, i.e., it employs lagged explanatory variables. It is possible that due to certain firm-specific or market frictions the impact of the explanatory variables is reflected in brand equity with a one-period lag. The results indicate that there is a significant dynamics that originates in gross profit and research and development expense. These variables are further combined with the non-lagged ones from the basic model and this resulted in regression (5) being the optimal model. Clearly, there are improvements in the $\bar{R}^{2}$ and the Ramsey statistic, relative to the model (2), but regression (5) is still inferior to the basic model (1).

A last exploration based on the model (4) concerns the potential presence of non-linearities. All of the explanatory variables are squared and the only statistically significant coefficient (at 5\% significance) is found for the research and development variable. Next, this variable is combined with the basic model and that produced regression (6) as the optimal non-linear model. Note that the coefficient on the squared term changed the sign, but remained statistically significant and very small in magnitude.

Table 2: Least Squares Estimates

\begin{tabular}{|c|c|c|c|c|c|c|}
\hline $\begin{array}{c}\text { explanatory } \\
\text { variables }\end{array}$ & (1) & (2) & (3) & (4) & (5) & (6) \\
\hline constant & $\begin{array}{c}1.28 \mathrm{e} 09 \\
(2.38 \mathrm{e} 09)\end{array}$ & $\begin{array}{l}5.93 \mathrm{e} 09^{* *} \\
(2.38 \mathrm{e} 09)\end{array}$ & $\begin{array}{c}1.71 \mathrm{e} 09 \\
(2.39 \mathrm{e} 09)\end{array}$ & $\begin{array}{c}1.14 \mathrm{e} 10 * * * \\
(2.02 \mathrm{e} 09)\end{array}$ & $\begin{array}{c}.73 \mathrm{e} 09^{* *} \\
(2.36 \mathrm{e} 09)\end{array}$ & $\begin{array}{c}4.21 \mathrm{e} 09^{* * *} \\
(2.46 \mathrm{e} 09)\end{array}$ \\
\hline$g p$ & $\begin{array}{c}0.8743 * * \\
(0.3509)\end{array}$ & $\begin{array}{l}0.4080^{*} \\
(0.2421)\end{array}$ & - & - & - & - \\
\hline$a e$ & $\begin{array}{l}-0.7807 \\
(4.0813)\end{array}$ & - & - & - & - & - \\
\hline rde & $\begin{array}{c}3.6562 * * \\
(1.4571)\end{array}$ & $\begin{array}{c}2.4352 * * \\
(1.0514)\end{array}$ & - & - & $\begin{array}{c}2.0760 * * \\
(0.9271)\end{array}$ & $\begin{array}{c}8.4383 * * * \\
(1.9448)\end{array}$ \\
\hline$g p_{t-1}$ & - & - & $\begin{array}{c}0.6825 * * \\
(0.3273)\end{array}$ & - & $\begin{array}{c}0.6204 * * * \\
(0.2336)\end{array}$ & - \\
\hline$a e_{t-1}$ & - & - & $\begin{array}{c}-0.0969 \\
(4.3331)\end{array}$ & - & - & - \\
\hline$r d e_{t-1}$ & - & - & $\begin{array}{c}4.7235^{* * * *} \\
(1.4089)\end{array}$ & - & - & - \\
\hline$g p^{2}$ & - & - & - & $\begin{array}{l}1.14 \mathrm{e}-11 * \\
(5.96 \mathrm{e}-12)\end{array}$ & - & - \\
\hline$a e^{2}$ & - & - & - & $\begin{array}{l}-4.06 \mathrm{e}-10 \\
(5.06 \mathrm{e}-10)\end{array}$ & - & - \\
\hline$r d e^{2}$ & - & - & - & $\begin{array}{c}3.42 \mathrm{e}-10^{* *} \\
(1.46 \mathrm{e}-10)\end{array}$ & - & $\begin{array}{c}-6.94 \mathrm{e}-10^{* *} \\
(2.83 \mathrm{e}-10)\end{array}$ \\
\hline $\bar{R}^{2}$ & 0.5739 & 0.2916 & 0.5614 & 0.2100 & 0.3448 & 0.3151 \\
\hline observations & 80 & 104 & 79 & 104 & 103 & 108 \\
\hline $\begin{array}{c}\text { Ramsey } \\
\text { (p-values) }\end{array}$ & 0.1307 & 0.0031 & - & - & 0.0280 & 0.1192 \\
\hline
\end{tabular}

The Ramsey statistic and the $\bar{R}^{2}$ further signify that non-linearities are to a certain extent important for brand equity determination. As in this work we choose not to utilize a more sophisticated non-linear model, the investigation of the nature of non-linear effects in the model is open to future research.

The main message from this exercise is that the empirical results reported that all of the considered variables are informative for brand equity modeling. The striking and novel evidence is the presence of dynamics and non-linear effects. 


\section{DISCUSSION}

One noteworthy observation is that advertising has the least significant relationship with brand equity based on current and previous year data. However, advertising, as well as gross profit, showed reasonable increases in significance when examined based on previous year data, substantiating a lag approach. The regression illustrated that the three variables together have a reasonable significance in explaining brand equity, but not enough to be considered statistically sufficient. As more variables are added, possibly some customer-based, the significance should increase. This is confirmed in earlier work. Both financial-based and customer-based measures appear crucial in fully explaining brand equity. The methodology Interbrand uses takes this into account and applies both measurement types.

Some of the limitations of this research have been previously explained regarding the collection of data, but there have been others regarding the type of data and results. The data is limited in its breadth as the majority of responses are based on American companies due to the ease of comparison with one currency (US\$). Additionally, the sample type includes a wide variety of company sizes ranging from enormous multi-nationals like Ford, Toyota and IBM to smaller companies like Fedex and Starbucks. This disparity in financial performance may limit applicable inferences regarding the results of this study and the interpretations of these results to other companies. The Interbrand measure of brand equity is also a possible limitation. Although it has been referenced numerous times by scholars, the Interbrand method may only provide one viewpoint in an examination of a complex relationship between brand equity and different valuation methods. To reduce this limitation, a similar approach can be used with a different valuation method.

Future research in the field of brand equity utilizing analogous research methodology can be conducted in a variety of different ways. With a longer sampling frame, causality may become a viable testing direction. It may be useful in understanding the simultaneous nature of gross profit and brand equity. Does gross profit drive brand equity, or does brand equity drive gross profit? A larger sample size and longer period of study may provide further foundation to the effect that these variables have on brand equity. Another approach can focus more on the examination of specific margins, which will be useful in reducing the different firm sizes in the sample. Examining the gross margin of companies will allow for a comparable field of analysis. However, this should be considered for specific industries since the acceptable norm for gross margin in one industry may not be acceptable in another industry. As the output of the regression analysis is both rich and intriguing, further investigation into the observed dynamics of the variables is warranted. Finally, it would be optimal to run a panel estimation, however this particular study did not yield enough data to support that approach.

\section{Managerial Implications}

The most evident managerial implication resulting from this study is for the augmented attention to and observable significance of the examined independent variables. Comparable earlier studies found that increased expenditures in advertising and research and development generally led to higher degrees of brand equity, as is the case here. It is interesting that gross profit has the largest correlation with brand equity, illustrating that brand equity may not driven by gross profit, but rather high brand equity may lead to a company being able to charge a higher price, also previously supported.

Another inference is that the correlation levels increased based on previous years data. This is interesting to managers as it supports the fact that short-term expenses (in advertising and research and development) provide long-term results. This findings offer statistical support that expenses incurred in building a brand cannot be viewed from a short-term perspective and that companies should be using a longer time period in measuring the success of brands, similar to investments. 


\section{REFERENCES}

1. Aaker, David A. (1991). Managing Brand Equity, New York: The Free Press

2. (1996). Measuring Brand Equity Across Products and Markets, California Management Review, 38, 3, 102-120

3. Agarwal, Manoj K. and Rao, Vithala R. (1996). An Empirical Comparison of Consumer-Based Measures of Brand Equity, Marketing Letters, 7 (3), 237-247

4. Ailawadi, Kusum L., Lehmann, Donald R., and Neslin, Scott A. (2003). Revenue Premium as an Outcome Measure of Brand Equity, Journal of Marketing, 67 (4), 1-17

5. Apelbaum, Eidan, Gerstner, Eitan, and Naik, Prasad A. (2003). The Effects of Expert Quality Evaluations Versus Brand Name on Price Premiums, Journal of Product and Brand Mangement, 12 (32) 154-165

6. Baldinger, Allan L., and Rubinson, Joel (1997). The Jeopardy in Double Jeopardy, Journal of Advertising Research, Nov/Dec, 37 (6), 37-49

7. Berry, L.L. (2000). Cultivating Service Brand Equity, Journal of the Academy of Marketing Science, 28, 128-137

8. Bristow, Dennis N., Schneider, Kenneth C., and Schuler, Drue K. (2002). The Brand Dependence Scale: Measuring Consumers; Use of Brand Name to Differentiate Among Product Alternatives, Journal of Product and Brand Management, 11 (6), 343-356

9. Byrnes, Nanette, Berner, Robert, and Zellner, Wendy (2005). Branding: Five New Lessons, Business Week, 3920, 26

10. Chen, Arthur Cheng-Hsui (2001). Using Free Association to Examine the Relationship Between the Characteristics of Brand Associations and Brand Equity, Journal of Product and Brand Management, 10 (6), 439-451

11. Cobb-Walgren, Cathy J., Ruble, Cynthia A., and Donthu, Naveen (1995). Brand Equity, Brand Preference, and Purchase Intent, Journal of Advertising, 24 (3), 25-40

12. Cook, William A. (1997). The Advertiser and Brand Equity: Superhero or Wizard of Odds, Journal of Advertising Research, Nov/Dec, 37 (6), 6

13. Ehrenberg, Andrew (1997a). Description and Prescription, Journal of Advertising Research, Nov/Dec, 37 (6), 17-22

14. Ehrenberg, Andrew (1997b). Differentiation and Salience, Journal of Advertising Research, Nov/Dec, 37 (6), 7-14

15. Faircloth, James B., Capella, Louis M., and Alford, Bruce L. (2001). The Effect of Brand Attitude and Brand Image on Brand Equity, Journal of Marketing Theory and Practice, 9 (3), 61-75

16. Farquhar, Peter H. (1989). Managing Brand Equity, Marketing Research, 1, 24-33

17. Farr, Andy, and Hollis, Nigel (1997). What Do You Want Your Brand To Be When It Grows Up: Big and Strong? Journal of Advertising Research, Nov/Dec, 37 (6), 23-45

18. Feldwick, Paul (1996). What is Brand Equity Anyway, and How Do You Measure It? Journal of the Market Research Society, 38 (2), 85-104

19. Granger, C.W.J. (1969). Investigating Causal Relations by Econometric Methods and Cross-Spectral Methods, Econometrica, 34, 424-438.

20. Kaikati, Jack G., and Kaikati, Andrew M. (2003). A Rose By Any Other Name: Rebranding Campaigns that Work, The Journal of Business Strategy, 24 (6), 17-23

21. Keller, K.L. (1993). Conceptualizing, Measuring, and Managing Customer-Based Brand Equity, Journal of Marketing, 57 (1), 1-22

22. Kotler, Philip H. (1996). Principles of Marketing, $7^{\text {th }}$ ed. Englewood Cliffs, NJ: Prentice-Hall

23. Lassar, Walfried, Mittal, Banwari, and Sharma, Arun (1995). Measuring Customer-Based Brand Equity, Journal of Consumer Marketing, 12 (4), 11-19

24. Mackay, M.M. (2001). Evaluation of Brand Equity Measures: Further Empirical Results, Journal of Product and Brand Management, 10 (1), 38-51

25. Mahajan, Vijay, Vithala, R. Rao, and Srivastava, Rajendra K. (1994). An Approach to Assess the Importance of Brand Equity in Acquisition Decisions, Journal of Product Innovation Management, 11, 221-235 
26. Seetharaman, A. Nadzir, Zainal Azlan Bin Mohd, and Gunalan, S. (2001). A Conceptual Study on Brand Valuation, Journal of Product and Brand Management, 10, 243-256

27. Simon, C. J. and Sullivan, M. W. (1993). The Measurement and Determinants of Brand Equity: A Financial Approach, Marketing Science, 12 (4), 28-52

28. Tollington, Tony (1999). The Brand Accounting Side-Show, The Journal of Product and Brand Management, 8 (3), 204-220

29. Washburn, J.H. and Plank, R.E. (2002). Measuring Brand Equity: An Evaluation of a Customer-Based Brand Equity Scale. Journal of Marketing Theory and Practice, 10 (1), 46-62

30. Winters, Lewis C. (1991). Brand Equity Measures: Some Recent Advances, Marketing Research, 3 (4), 7072

31. Wood, Lisa M. (2004). Dimensions of Brand Purchasing Behavious: Consumers in the 18-24 Age Group, Journal of Consumer Behavior, 4 (1), 9-24

32. Yoo, Boonghee, Donthu, Naveen, and Lee, Sungho (2000). An Examination of Select Marketing Mix Elements and Brand Equity, Journal of the Academy of Marketing Science, 28 (2), 195-211

33. Yoo, Boonghee and Donthu, Naveen (2001). Developing and Validating a Multidimensional ConsumerBased Brand Equity Scale, Journal of Business Research, 52, 1-14

\section{NOTES}

